\title{
Characterisation and application of glycanases secreted by Aspergillus terreus CCMI 498 and Trichoderma viride CCMI 84 for enzymatic deinking of mixed office wastepaper
}

\author{
S. Marques ${ }^{a}$, H. Pala ${ }^{b}$, L. Alves ${ }^{a}$, M.T. Amaral-Collaço ${ }^{a}$, F.M. Gama ${ }^{b}$, \\ F.M. Gírio ${ }^{\mathrm{a}, *}$ \\ a Unidade de Fisiologia Microbiana e Bioprocessos, Departamento de Biotecnologia, INETI, Estrada do Paço do Lumiar 22, \\ 1649-038 Lisbon, Portugal \\ ${ }^{\mathrm{b}}$ Centro de Engenharia Biológica-IBQF, Universidade do Minho, Largo do Paço, 4719 Braga, Portugal
}

Received 21 December 2001; received in revised form 5 June 2002; accepted 22 July 2002

\begin{abstract}
Two enzymatic extracts obtained from xylan-grown Aspergillus terreus CCMI 498 and cellulose-grown Trichoderma viride CCMI 84 were characterised for different glycanase activities. Both strains produce extracellular endoxylanase and endoglucanase enzymes. The enzymes optimal activity was found in the temperature range of $45-60{ }^{\circ} \mathrm{C}$. Endoglucanase systems show identical activity profiles towards temperature, regardless of the strain and inducing substrate. Conversely, the endoxylanases produced by both strains showed maximal activity at different $\mathrm{pH}$ values (from 4.5 to 5.5), being the more acidic xylanase produced by $T$. viride grown on cellulose. The endoglucanase activities have an optimum $\mathrm{pH}$ at 4.5-5.0. The endoxylanase and endoglucanase activities exhibited high stability at $50{ }^{\circ} \mathrm{C}$ and $\mathrm{pH}$ 5.0. Mannanase, $\beta$-xylosidase, and amylase activities were also found, being the first two activities only present for T. viride extract. These two enzymatic extracts were used for mixed office wastepaper (MOW) deinking. When the enzymatic extract from $T$. viride was used, a further increase of $24 \%$ in ink removal was obtained by comparison with the control. Both enzymes contributed to the improvement of the paper strength properties and the obtained results clearly indicate that the effective use of enzymes for deinking can also contribute to the pulp and paper properties improvement.
\end{abstract}

(C) 2002 Elsevier Science B.V. All rights reserved.

Keywords: Hemicellulase; Endoglucanase; Amylase; Enzymatic deinking; Aspergillus terreus; Trichoderma viride

* Corresponding author. Tel.: +351-21-716-5181; fax: + 351-21-716-3636

E-mail address: francisco.girio@mail.ineti.pt (F.M. Gírio).

\section{Introduction}

The paper recycling mills must perform a deinking operation for removal of ink particles prior to wastepaper recyling. This operation 
involves the ink particles dislodgement from the fibre surface and the separation of the dispersed ink from fibre suspensions by washing or flotation (Prasad et al., 1992; Bajpai et al., 1999). The most difficult raw material for deinking is mixed office wastepaper (MOW) (Prasad, 1993; Gübitz et al., 1998). Indeed, photocopiers and laser printers physically bind the ink (thermosetting toners consisting of non-dispersible synthetic polymers) to the fibres as a result of high heat, making it difficult and expensive to remove by conventional chemical methods (Jeffries et al., 1993, 1994). Most of the conventional deinking techniques require large amounts of chemical agents, such as sodium hydroxide, sodium carbonate, diethylenetriaminepentacetic acid, sodium silicate, hydrogen peroxide and surfactants (Prasad et al., 1993; Woodward et al., 1994), resulting in a costly wastewater treatment to meet the environmental regulations (Prasad et al., 1992). Alternatively, enzyme usage has been reported to be a potentially efficient and less polluting solution to overcome this disposal problem (Prasad et al., 1992; Putz et al., 1994). Lipases and esterases can degrade vegetable-oil-based inks, while pectinases, hemicellulases, cellulases and ligninolytic enzymes are believed to alter fibre surfaces or bonds in the vicinity of ink particles thereby facilitating subsequent ink removal (Zeyer et al., 1994; Ow et al., 1995; Welt and Dinus, 1995; Anne et al., 1999). Most of the literature describing deinking assays uses blends of commercial cellulases/hemicellulases enzymes (Duff et al., 1995; Zeyer et al., 1995). However, these blends usually contain other chemicals (e.g. protein stabilisers) that are not accounted for in the evaluation of enzymatic deinking performance.

In order to better understand the enzymatic deinking mechanism involved in the ink/fibre interaction, it is essential to use the well-characterised hydrolases from known microbial sources. In the present work, we have produced two extracellular enzymatic extracts from two fungi, xylan-grown Aspergillus terreus CCMI 498 and cellulose-grown Trichoderma viride CCMI 84. The crude endoxylanase and endoglucanase activities were characterised in terms of $\mathrm{pH}$ and temperature profiles and stability and apparent molecular mass from zymogram analysis. These extracellular enzymatic extracts were further used in deinking trials of MOW. A comparative performance of both enzymatic systems was carried out by measuring the deinking efficiency and particle size variation together with the evaluation of the paper strength properties.

\section{Materials and methods}

\subsection{Microorganisms}

Two fungi deposited in the culture collection of industrial microorganisms (CCMI) from INETI (Lisboa, Portugal), A. terreus CCMI 498 and $T$. viride CCMI 84, were used in this work. Stock cultures were routinely maintained on potato dextrose agar slants at $4{ }^{\circ} \mathrm{C}$, and transferred into fresh medium once a month.

\subsection{Growth conditions}

The culture medium used for enzyme production consisted of (per litre of distilled water): $\mathrm{KH}_{2} \mathrm{PO}_{4}, 2.0 \mathrm{~g} ;\left(\mathrm{NH}_{4}\right)_{2} \mathrm{SO}_{4}, 3.0 \mathrm{~g} ; \mathrm{MgSO}_{4}$. $7 \mathrm{H}_{2} \mathrm{O}, 0.3 \mathrm{~g} ; \mathrm{CaCl}_{2}, 0.2 \mathrm{~g} ; \mathrm{CoCl}_{2}, 1.7 \mathrm{mg}$; peptone, $1.0 \mathrm{~g}$; Tween 80, $185 \mu \mathrm{l}$; mineral solution (Vishniac and Santer, 1957), $0.25 \mathrm{ml}$; urea, $0.3 \mathrm{~g}$. This medium was supplemented with the following carbon source $(1 \%)$ : oat spelts xylan (Sigma, St. Louis, USA) for $A$. terreus and microcrystalline cellulose Avicel (Merck, Darmstadt, Germany) for T. viride growth.

Both fungi were grown at $28{ }^{\circ} \mathrm{C}$ in Erlenmeyer flasks shaken at $150 \mathrm{rpm}$ on an orbital shaker, and samples were collected during 15 days. At the maximal endoxylanase or endoglucanase volumetric activity the culture broth was filtered and the cell-free broth was further used both for enzyme characterisation and for deinking trials. For the latter assays, the crude enzyme was previously freeze-dried.

\subsection{Enzymatic assays}

All enzyme assays were carried out at $50{ }^{\circ} \mathrm{C}$ in $0.05 \mathrm{M} \mathrm{pH} 5.0$ sodium citrate buffer (unless 
otherwise stated), using suitable diluted enzyme samples.

Endo- $\beta-1,4$-xylanase $(1,4-\beta-D-x y l a n$ xylanhydrolase; EC 3.2.1.8), endo- $\beta$-1,4-glucanase (CMCase; $1,4-\beta$-D-glucan glucanohydrolase; EC 3.2.1.4), endo- $\beta$-1,4-mannanase (1,4- $\beta$-D-mannan mannanohydrolase; EC 3.2.1.78) and $\alpha$-1,4-amylase (1,4- $\alpha$-D-glucan glucanohydrolase; EC 3.2.1.1) activities were determined by measuring (after an incubation time of $15 \mathrm{~min}$ ) the release of reducing sugars from the following substrates: $1 \%(\mathrm{w} / \mathrm{v})$ oat spelts xylan (Sigma), 1\% (w/v) carboxymethyl cellulose (BDH, Poole, England), 0.5\% (w/v) locust bean gum (Sigma) and 1\% (w/v) starch (Merck). Filter paper activity (FPase), which describes the overall cellulolytic activity, was assayed using Whatman Number 1 filter paper (about $50 \mathrm{mg}$ ). Reducing sugars released were assayed by the dinitrosalicylic acid method (Miller, 1959). One unit (U) of enzymatic activity was expressed as $1 \mu \mathrm{mol}$ of xylose, glucose or mannose equivalents released per minute, under the specified conditions.

$\beta$-Xylosidase (1,4- $\beta$-D-xyloside xylohydrolase; EC 3.2.1.37) activity was determined using the synthetic substrate $p$-nitrophenyl $\beta$-D-xylopyranoside (Sigma) as described by Li et al. (1993). One unit of activity was defined as the amount of enzyme which catalyses the release of $1 \mu \mathrm{mol}$ $\min ^{-1}$ of $p$-nitrophenol under the assay conditions.

\subsection{Characterisation of endoxylanase and endoglucanase activities}

Endo- $\beta-1,4$-xylanase and endoglucanase activities present on the cell-free broths of A. terreus and $T$. viride were characterised in terms of temperature and $\mathrm{pH}$ profiles and stability.

The temperature effect on the endo- $\beta-1,4$-xylanase and endoglucanase activities was analysed between 3 and $80{ }^{\circ} \mathrm{C}$, at $\mathrm{pH} 5.0$.

For the optimum $\mathrm{pH}$ determination, $0.05 \mathrm{M}$ buffer solutions ranging from $\mathrm{pH} 1.0$ to 9.0 were used at the optimal temperature previously determined for each enzyme. $\mathrm{HCl}-\mathrm{KCl}$ buffer was used for $\mathrm{pH}$ range between 1.0 and 2.2, glycine- $\mathrm{HCl}$ buffer for $\mathrm{pH} 2.2-3.0$, sodium citrate buffer for
$\mathrm{pH} 3.0-6.0$, sodium phosphate buffer for $\mathrm{pH} 6.0-$ 8.0 and Tris $-\mathrm{HCl}$ buffer for $\mathrm{pH} 8.0-9.0$.

To study the stability of endoxylanase and endoglucanase activities at the $\mathrm{pH}$ and temperature conditions used for the deinking assays, enzyme preparations in $0.05 \mathrm{M} \mathrm{pH} 5.0$ sodium citrate buffer were incubated at $50{ }^{\circ} \mathrm{C}$ during $2 \mathrm{~h}$ and assayed for the residual activity.

\subsection{Endoxylanase and endoglucanase zymograms}

Native polyacrylamide gel electrophoresis (PAGE) was carried out in polyacrylamide gel gradient concentration $(7.5-20 \%)$ containing $0.1 \%$ (w/v) oat spelts xylan (Sigma) or carboxymethyl cellulose (BDH) for endoxylanase and endoglucanase activities detection, respectively. Electrophoresis was run at constant voltage $(175 \mathrm{~V})$ at $4{ }^{\circ} \mathrm{C}$ for $22 \mathrm{~h}$. The crude enzymes were applied in a suitable volume containing a total endoxylanase or endoglucanase activity of 150 and $75 \mathrm{mU}$, respectively. The gels were incubated for $15 \mathrm{~min}$ at $50{ }^{\circ} \mathrm{C}$ in $0.05 \mathrm{M}$ sodium citrate buffer $(\mathrm{pH}$ 5.0) and submerged in $0.1 \%(\mathrm{w} / \mathrm{v})$ Congo Red solution during $10 \mathrm{~min}$. After gel washing with $1 \mathrm{M} \mathrm{NaCl}$ the enzyme bands were clearly obtained.

The apparent enzymes molecular mass were determined by native electrophoresis using protein standards ranging from 67 to $669 \mathrm{kDa}$ (HMW Electrophoresis Calibration Kit from Amersham Pharmacia Biotech, Uppsala, Sweden).

\subsection{Deinking assays}

The paper pulp used in this work was kindly supplied by the paper private company Renova, S.A. (Torres Novas, Portugal) and consisted of a MOW.

The deinking process included enzymatic pulping and a fibre/ink separation stage, and $25 \mathrm{~g}$ of pulp (oven-dry basis) was processed. The pulp suspensions were prepared by disintegrating the samples in $0.05 \mathrm{M}$ sodium citrate buffer, $\mathrm{pH}$ 5.0, for $10 \mathrm{~min}$. This mechanical treatment allowed fibre separation without changing their structural properties. After this step, the enzyme was added to the mixer according to the dosages mentioned in Table 1. 
Table 1

Enzyme dosages applied in the mixed wastepaper office deinking assays

\begin{tabular}{lll}
\hline Enzyme dosage ( $\mathrm{U} \mathrm{g}^{-1}$ dry pulp) & \multicolumn{2}{l}{ Enzyme source } \\
\cline { 2 - 3 } & A. terreus & $T$. viride \\
\hline Endo- $\beta$-1,4-xylanase & 1.30 & 1.30 \\
$\beta$-Xylosidase & 0.00 & 0.40 \\
Endoglucanase & 0.02 & 0.09 \\
$\quad$ FPase & 0.03 & 0.04 \\
Mannanase & 0.00 & 0.77 \\
Amylase & 0.06 & 0.08 \\
\hline
\end{tabular}

The enzymatic preparations were diluted $(10 \%$ of the total reaction volume) in order to achieve a better dispersion. The reaction with the pulp occurred for $30 \mathrm{~min}$ at $11 \%$ consistency, $\mathrm{pH} 5.0$ and $50{ }^{\circ} \mathrm{C}$, with continuous slow mixing, as described in previous work (Pala et al., 2001). A consistency of $11 \%$ was chosen because it prompts fibre/fibre contact and favours ink detachment. The deinking assays were always carried out at a temperature of $50{ }^{\circ} \mathrm{C}$ and $\mathrm{pH} 5.0$ for both crude enzyme mixtures. The $\mathrm{pH}$ chosen was the average among the optimal for all the activities produced by both strains. The selected temperature was the lowest value among the different optimal temperatures for all the activities in order to preserve the enzyme thermostability at a maximum level. To finish up the trial, the enzyme was deactivated by boiling the pulp for $5 \mathrm{~min}$. Finally, the pulp was washed with tap water $(\approx 30$ 1) through a 200 mesh wire and recovered for testing. Washing was selected to promote the fibre/ink separation due to the reduced size of the ink particles present in the pulp stock. A preliminary set of assays showed that this methodology of ink removal is more efficient than flotation for this particular paper pulp: $14 \%$ of ink removal relative to the nontreated pulp (flotation) versus 25\% (washing). In order to accurately estimate the role of the enzymatic action control assays (with denatured enzyme) were made in parallel. Each experimental condition (enzymatic assay or control) was assayed twice and a good reproducibility was found. The coefficients of variation of the determined physical properties and ink amount never exceeded 2 and $5 \%$, respectively.

\subsection{Deinking evaluation}

The efficiency of the enzymatic deinking treatment was evaluated by determination of the physical and mechanical properties of pulp and paper (ISO standard procedures) and comparison by image analysis of the amount of ink present in paper sheets, before (handsheets made from the initial stock) and after treatment (with active or denatured enzyme).

The image analysis system is composed of a magnification lens, charge-coupled device (CCD) camera, image display and computer. All the images were acquired with the same magnification and lightning in order to obtain comparable results. A $4 \times$ objective was chosen, as a reasonable compromise between image enlargement and analysed area. All handsheets were analysed on the same side. Particle count, shapes and sizes were examined using a commercially available software (Globalab Image). To ensure image analysis results in reproducibility, a suitable threshold value was selected to identify the contaminants and maintained in all performed analysis with the same kind of pulp. For each handsheet, 40 images were retained and treated. The area analysed in each image of 438528 pixels was about $13 \mathrm{~mm}^{2}$. The total area analysed in each handsheet was about $5.2 \mathrm{~cm}^{2}$. The dimension of the smallest detectable particle is $297 \mu \mathrm{m}^{2}$ (10 pixels), equivalent to a diameter of $19 \mu \mathrm{m}$, assuming a spherical geometry.

\subsection{Physical and mechanical properties determination}

Handsheet preparation and determinations of the pulp and paper properties followed the usual standard procedures: drainage rate (ISO 5267/1), burst (ISO 2758), tensile strength (ISO 1924/2) and tear (ISO 1974) indices. 


\section{Results and discussion}

\subsection{Enzyme production by fungi}

Both strains used in this work, A. terreus CCMI 498 and T. viride CCMI 84, were able to produce extracellular endo- $\beta-1,4$-xylanases, endoglucanases and amylases. The endoglucanase and amylase activities were detected in lower levels than the endoxylanase activities. No $\beta$-xylosidase or endomannanase activity was detected in the culture broth from $A$. terreus grown on oat spelts xylan.

The highest xylanolytic (endo- $\beta$-1,4-xylanase activity of $26.9 \mathrm{U} \mathrm{ml}^{-1}$ for $A$. terreus grown on oat spelts xylan; endo- $\beta-1,4$-xylanase activity of $1.8 \mathrm{U} \mathrm{ml}^{-1}$ and $\beta$-xylosidase activity of $0.53 \mathrm{U}$ $\mathrm{ml}^{-1}$ for $T$. viride grown on cellulose Avicel) and endoglucanase (CMCase activity of $0.070 \mathrm{U} \mathrm{ml}^{-1}$ for $A$. terreus grown on oat spelts xylan and 0.207 $\mathrm{U} \mathrm{ml^{-1 }}$ for $T$. viride grown on cellulose Avicel) activities produced by both fungal strains were obtained after about 15 days of growth. Hrmová et al. (1989) reported the maximal endo- $\beta-1,4-$ xylanase production of about $4 \mathrm{U} \mathrm{ml}^{-1}$ after 3 days of growth on $1 \%$ xylan using $A$. terreus strain F-413 which is significantly lower than that obtained in this work.

\subsection{Endoxylanase and endoglucanase characterisation}

\subsubsection{Temperature and $p H$ profiles and stability}

The temperature profiles of endoxylanase and endoglucanase activities from $A$. terreus and $T$. viride are shown in Fig. 1. The extracellular xylanolytic system is strain/substrate dependent as shown in Fig. 1A. However, both strains produce endoxylanases exhibiting optimal activity in the range of $45-60{ }^{\circ} \mathrm{C}$, the optimal activity for A. terreus grown on xylan being slightly higher than the optimal xylanase activity from $T$. viride grown on cellulose. Conversely, the extracellular cellulolytic systems show identical activity profiles towards the temperature regardless of the strain and the inducing substrate (Fig. 1B). The endoglucanases produced displayed maximal activity for a temperature range between 50 and $60{ }^{\circ} \mathrm{C}$. This agrees with previous literature that reports
A)

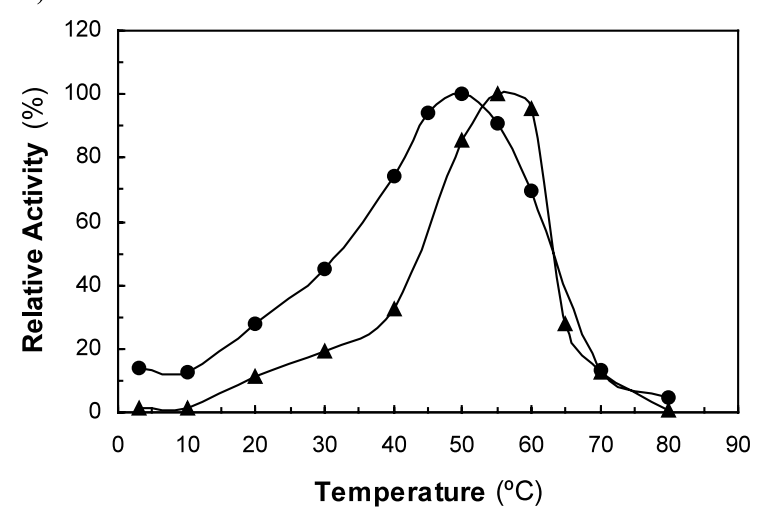

B)

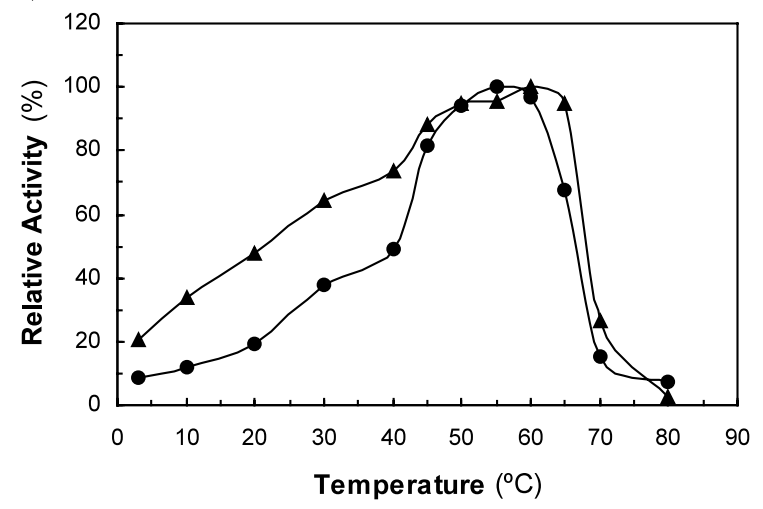

Fig. 1. Effect of temperature on glycanases activities ( $\mathrm{pH} 5.0$ ) produced by $A$. terreus CCMI 498 grown on oat spelts xylan (ム) and T. viride CCMI 84 grown on cellulose Avicel (O). Panel A, effect on endo- $\beta-1,4$-xylanase activity. Relative activity is expressed as a percentage of the respective maximum $\left(100 \%\right.$ of enzyme activity $=31.4$ and $0.95 \mathrm{U} \mathrm{ml}^{-1}$ for $A$. terreus and $T$. viride, respectively). Panel $\mathrm{B}$, effect on endoglucanase activity. Relative activity is expressed as a percentage of the respective maximum $(100 \%$ of enzyme activity $=0.079$ and $0.255 \mathrm{U} \mathrm{ml}^{-1}$ for $A$. terreus and $T$. viride, respectively).

the optimal temperature of $55{ }^{\circ} \mathrm{C}$ for both cellulase and xylanase for a strain of $T$. viride isolated from decomposed jute stacks (Gomes et al., 1992).

The $\mathrm{pH}$ profiles between 1.0 and 9.0 for endoxylanase and endoglucanase activities are shown in Fig. 2. In a similar way, the optimal xylanase activity towards $\mathrm{pH}$ differs with the strain origin and type of substrate whereas the endoglucanase activity profile is identical for both strains and inducing substrates. This suggests that different xylanase isoforms are being produced by both 

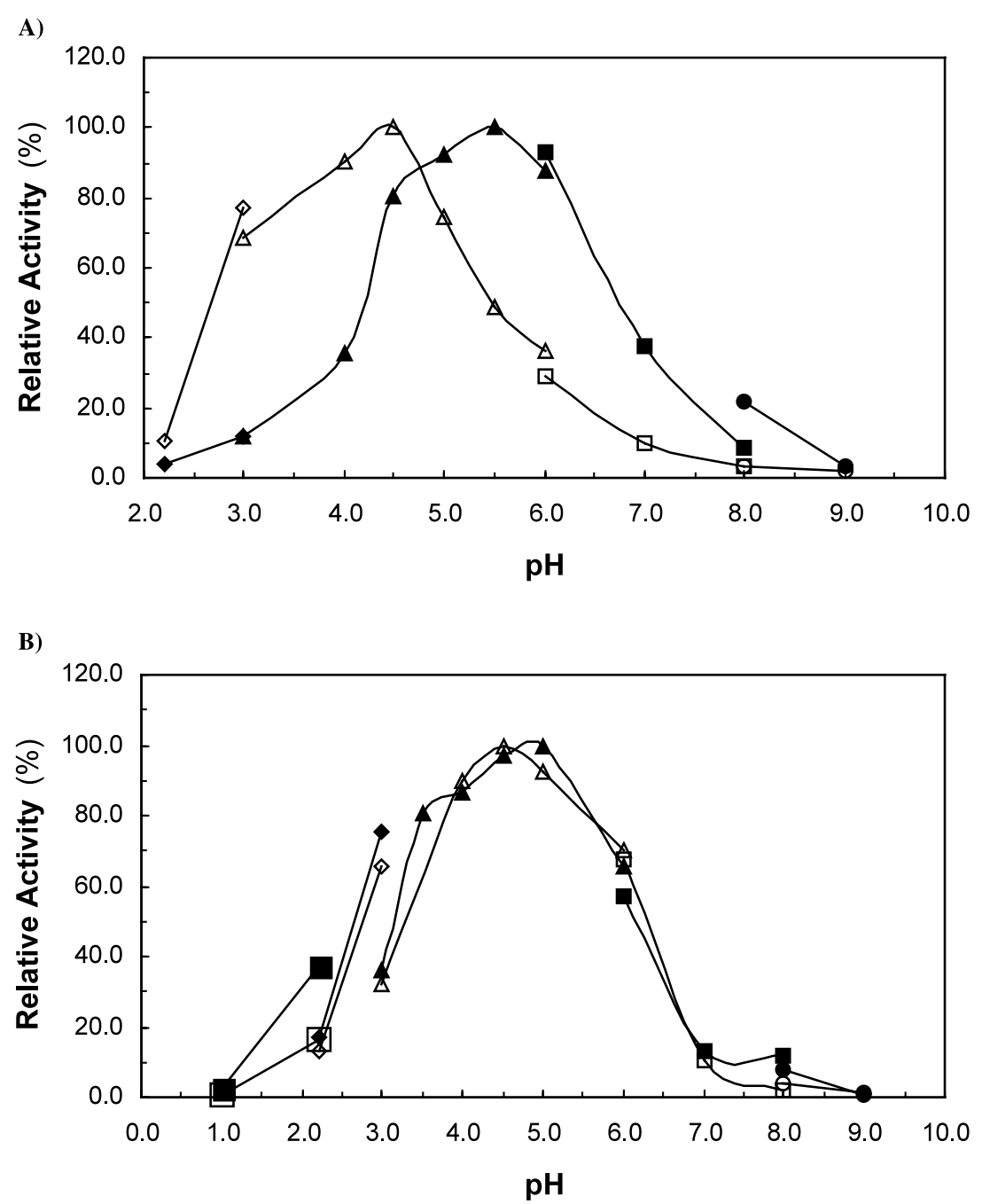

Fig. 2. Effect of $\mathrm{pH}$ on glycanases activities produced by A. terreus grown on oat spelts xylan (closed symbols) and T. viride grown on cellulose Avicel (open symbols). The ionic strength for all buffers was $0.05 \mathrm{M}$ : $(\mathbf{\square}), \mathrm{HCl}-\mathrm{KCl}$; $(\bullet)$, glycine- $\mathrm{HCl}$; ( $\mathbf{\wedge}$ ), sodium citrate; (ם), sodium phosphate; $(\bullet)$, Tris $-\mathrm{HCl}$. Panel A, effect on endo- $\beta-1,4$-xylanase activity $\left(55\right.$ and $50{ }^{\circ} \mathrm{C}$ for $A$. terreus and $T$. viride, respectively). Relative activity is expressed as a percentage of the respective maximum $\left(100 \%\right.$ of enzyme activity $=34.0$ and $1.3 \mathrm{U} \mathrm{ml} \mathrm{C}^{-1}$ for $A$. terreus and $T$. viride, respectively). Panel $\mathrm{B}$, effect on endoglucanase activity $\left(60\right.$ and $55{ }^{\circ} \mathrm{C}$ for $A$. terreus and T. viride, respectively). Relative activity is expressed as a percentage of the respective maximum ( $100 \%$ of enzyme activity $=0.079$ and $0.276 \mathrm{U}$ $\mathrm{ml}^{-1}$ for $A$. terreus and $T$. viride, respectively).

strains. The xylanases exhibited maximal activity for $\mathrm{pH}$ values of 4.5 and 5.5 being the more acidic xylanases produced by $T$. viride grown on cellulose (Fig. 2A). The endoglucanases displayed optimal activity in the $\mathrm{pH}$ range 4.5-5.0 (Fig. 2B). Gomes et al. (1992) for cellulose-grown T. viride reported the values of $\mathrm{pH} 5.2$ and 4.5 for the maximal activities of xylanase and cellulase, respectively. It must be noted, however, that endoglucanase activity is very dependent on the type of buffer used since for lower $\mathrm{pH}$ values $(2.0-3.0)$ the activity can double depending on the buffer solution.

Since in this work, we intend to study the effectiveness of using these enzymes for a specific industrial application (pulp deinking), apart from 
their $\mathrm{pH}$ and temperature optima, enzyme stability constitute a critical parameter. We did not find any significant decrease on glycanase activities after $30 \mathrm{~min}$ of incubation time. This was the time period used during the deinking assays. In fact, the main glycanase (xylanase) produced by $T$. viride and $A$. terreus retained nearly 80 and $95 \%$, respectively, of their original endoxylanase activities after a 30 -min preincubation at $50{ }^{\circ} \mathrm{C}$ and $\mathrm{pH}$ 5.0. Moreover, after $2 \mathrm{~h}$ of incubation the T. viride endoxylanase showed a $50 \%$ inactivation whereas the A. terreus endoxylanase still exhibited $93 \%$ of its original activity. The endoglucanases produced by both $T$. viride and $A$. terreus displayed even higher stability than the endoxylanases at the assayed conditions. After $2 \mathrm{~h}$, we have measured 100 and $95 \%$, respectively, of the original endoglucanase activities.

\subsubsection{Zymograms}

Fig. 3 shows the zymograms obtained for endoglucanases from both fungi. As can be observed, both strains produced multiple bands displaying endoglucanase activity. Four activity bands were detected for $A$. terreus, corresponding

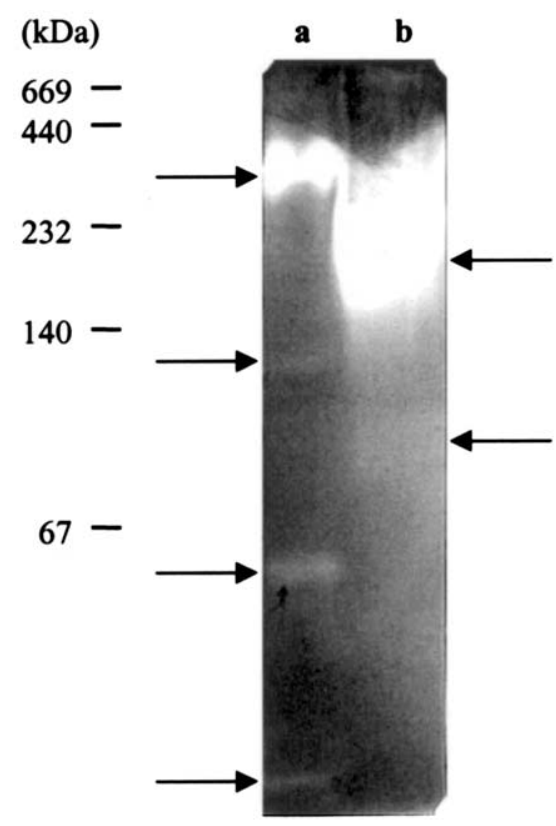

Fig. 3. Zymogram analysis of endoglucanase activity in supernatant filtrates from: (a) A. terreus; (b) T. viride. to proteins with apparent molecular masses of 250 (predominant), 100, 50 and $30 \mathrm{kDa}$. For T. viride, only two bands were detected corresponding to proteins with apparent molecular masses of 180 (predominant) and $80 \mathrm{kDa}$ (an ill-defined band). The higher molecular mass bands very likely correspond to protein aggregates. Further work currently in progress focuses on the identification and isolation of the active proteins. Probably, at least one endo-type cellulase is produced by each fungus, with molecular mass of approximately 30 and $80 \mathrm{kDa}$ for $A$. terreus and T. viride, respectively.

Zymogram analysis for detection of endoxylanase activity was also carried out but the obtained activity bands were not well defined. This could probably be explained by the fact that xylanase activity produced by both strains still exhibits significant levels (above $0.1 \mathrm{U} \mathrm{ml}^{-1}$ ) at the electrophoretic conditions of $4{ }^{\circ} \mathrm{C}$ and $\mathrm{pH} 8$. Therefore, during the time length of gel electrophoresis, the xylanases were still active and able to hydrolyse the gel xylan leading to the formation of a large clear zone after staining with Congo Red. Thus, the determination of the xylanase molecular masses is subject to gross estimations using this technique. Despite this problem that prevents an accurate estimation of the bands molecular mass, it was possible to observe that both strains produced enzymatic systems exhibiting very different molecular masses. A. terreus produces xylanase aggregates corresponding to very high apparent molecular masses (above $200 \mathrm{kDa}$ ) whereas $T$. viride produces a xylanolytic system with much lower apparent molecular masses (under $80 \mathrm{kDa}$ ) (data not shown).

\subsection{Deinking assays}

The evaluation of MOW deinking performance using glycanases from $A$. terreus and $T$. viride was carried out. The enzymatic dosages used in the deinking trials are shown in Table 1 . Table 2 shows the results obtained in terms of deinking efficiency and particle size variation. The deinking efficiency was calculated from the difference in residual ink areas between enzymatically deinked and control pulp divided by the residual ink area in control 
Table 2

Effect of the enzymatic treatment on ink removal

\begin{tabular}{|c|c|c|c|c|c|}
\hline & Ink area $(\mathrm{ppm})$ & $\begin{array}{l}\text { Deinking efficiency } \\
(\%)\end{array}$ & $\begin{array}{l}\text { Average particle size } \\
(\mu \mathrm{m})\end{array}$ & $\begin{array}{l}\text { Median particle size } \\
(\mu \mathrm{m})\end{array}$ & Solubilisation $(\%)$ \\
\hline $\begin{array}{l}\text { Non-treated } \\
\text { pulp }\end{array}$ & 5331 & - & 2065 & 746 & - \\
\hline Control & 3109 & - & 1882 & 822 & - \\
\hline A. terreus & 2850 & 8 & 2369 & 867 & 0.8 \\
\hline T. viride & 2372 & 24 & 2755 & 1037 & 1.1 \\
\hline
\end{tabular}

a Determined relative to the control.

pulp. We observe that considerable ink removal was attained simply due to the mechanical treatment. Indeed, when the non-treated pulp and the control (no enzyme action present) are compared, a $42 \%$ decrease in residual ink is detected. This is probably the result of environmental factors such as mixing, temperature, washing, which enables a partial release of the ink particles from the fibres due to a break down of physical/chemical bonds (Borchardt, 1993; Jobbins and Franks, 1997; Ackermann and Putz, 1999).

Both enzyme treatments showed substantial improvements in residual ink removal relative to the control assay. When the enzymatic extract from $T$. viride was added to the deinking trials a further increase of $24 \%$ in ink removal was obtained by comparison with the control (Table 2 ). The enzymatic extract from A. terreus was found to be less efficient since it removes only $8 \%$ more of the total ink amount compared with the control. When we observe the composition of the two enzymatic extracts, $A$. terreus extract is basically an endoxylanase extract whereas $T$. viride extract is a mixture of endoxylanase, mannanase and $\beta$-xylosidase (Table 1). The latter enzyme extract displays also 4.5-fold more endoglucanase activity than $A$. terreus extract. This wider range of glycanase activities present on the extracellular extract from $T$. viride might have an important contribution to make to the higher efficiency observed in the wastepaper deinking. Nonetheless, further studies involving characterisation of enzyme activities, including other nonmeasured activities, followed by the application of some purified enzymes, would be necessary to elucidate the exact role of each enzyme in the deinking process. Furthermore, other properties such as adsorption ability and processivity may be relevant since the enzymatic deinking process may partially result from a competition of the enzyme molecules and the ink particles towards the fibre surface.

The deinking efficiency of crude enzyme from $T$. viride is similar to that obtained by Prasad et al. (1992). These authors reported an increase in ink removal ranging from 29 to $36 \%$ using four different commercial cellulase/xylanase blends.

Conversely, we observed an increase in both average and median size of the ink particles for $T$. viride enzyme extract indicating that the amount of smaller particles decreases after the enzymatic treatment (Table 2). This enzymatic preparation may be more effective for the removal of smaller ink particles compared with larger ink particles. However, it must be remarked that the separation of the ink particles was accomplished by washing the fibres, a process, which removes more effectively the smaller particles. Prasad et al. (1992), Rushing et al. (1993) using only cellulases reported a particle size reduction from 16 to $37 \%$ depending on ink type. The enzymatic extract from $A$. terreus produced no significant changes in mean particle size of the specks.

It has been reported that the action of enzymes in pulp is affected by the accessibility of substrates in the fibre matrix (Suurnäkki et al., 1997). The main factors limiting the access of enzymes to woody materials are the specific surface area and the porosity, i.e. the median pore size of fibres. Thus, the molecular size and structure of enzyme are expected to be important factors when considering the limited accessibility of the substrates 
in fibre matrices (Suurnäkki et al., 1997). Since the molecular size depends on the steric configuration of the proteins as well as their molecular mass, a possible explanation for the higher deinking efficiency obtained using the enzymatic extract from $T$. viride should be derived from the lower molecular masses associated to the enzymatic complexes showing endoxylanase activity as already referred to for the zymogram analysis.

Fig. 4 shows the effect of the enzymatic treatment in the pulp properties. Both enzymes contributed to the improvement of the strength properties relative to the control, in the three strength tests (tensile, burst and tear indices), with the exception of the tear index which is not affected by the extract from $A$. terreus. These results support previous findings by other authors concerning the occurrence of either unchanged or enhanced strength properties, such as tensile and burst indices for paper handsheets obtained after

A)

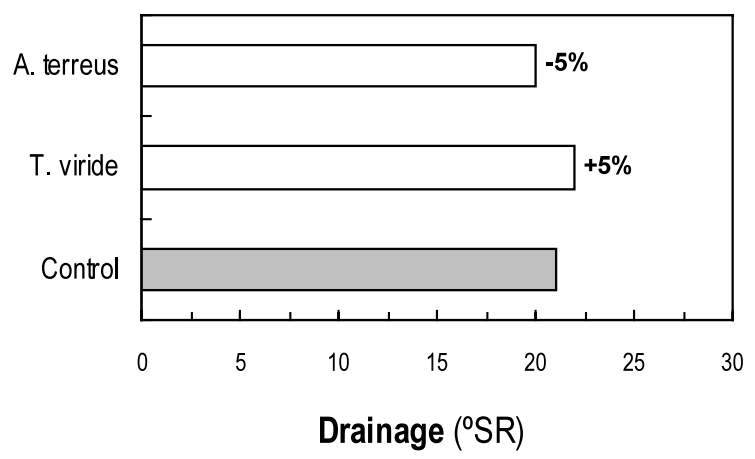

C)

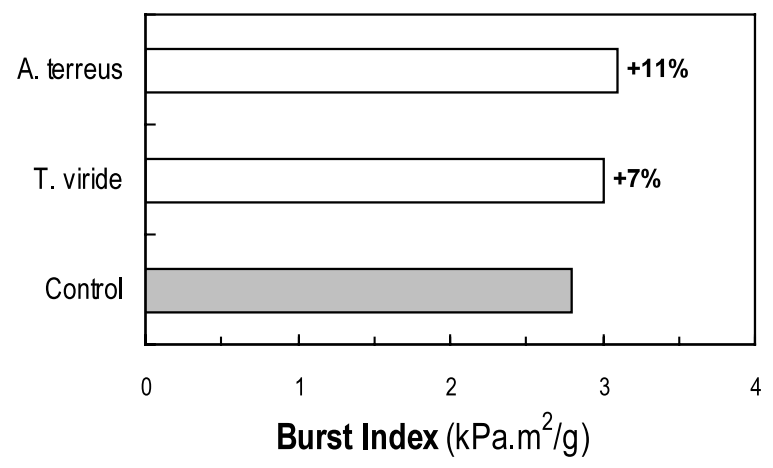

enzymatic deinking (Jeffries et al., 1994; Rutledge et al., 1994; Heise et al., 1996).

The present work revealed that enzymatic treatment caused no change in sheet density but slightly decreased the handsheets permeability (up to $8 \%$ after $A$. terreus treatment). This might indicate that although fibre collapsibility was not considerably altered, interfibre bonding was enhanced, thus justifying the strength improvement. This effect could be attributed to the enzymatic removal of small hemicellulose chains from the surface of the fibres. According to Fišerová et al. (1987) the hemicellulose content modification affects the bonding potential. The slightly higher fibre solubilisation after the pulp treatment with $T$. viride $(1.1$ vs. $0.8 \%)$ may explain the increased paper strength obtained in this case.

The pulp drainage rate was also increased by $5 \%$ when $A$. terreus enzyme extract was used. The enzyme extract from $T$. viride had no positive

B)

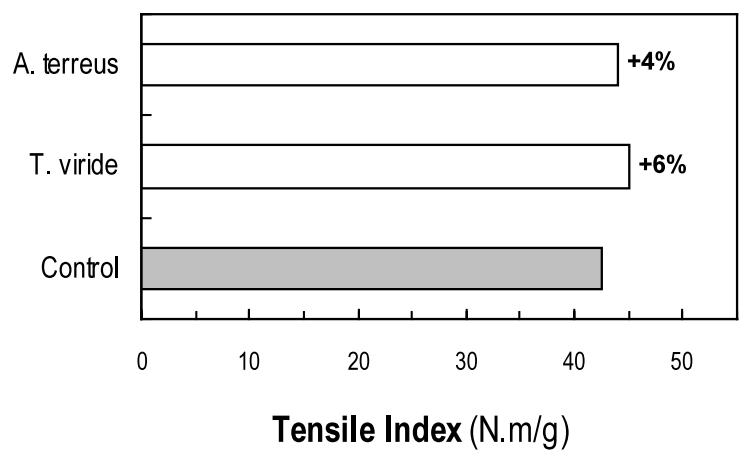

D)

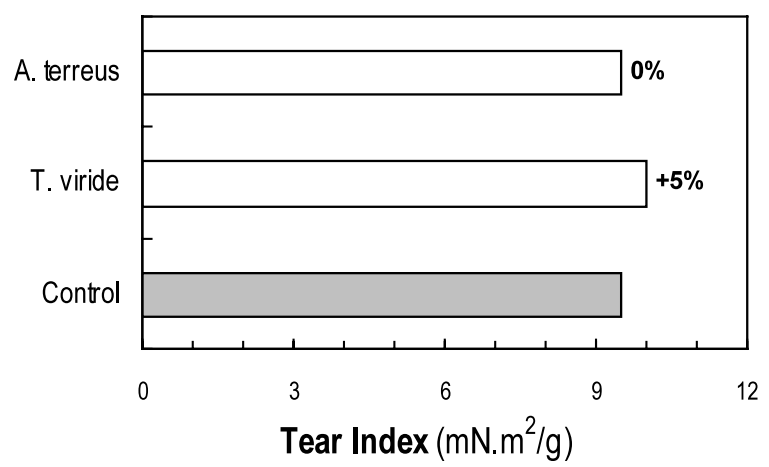

Fig. 4. Effect of the enzymatic treatment on the properties of wastepaper pulps: (A) drainage; (B) tensile index; (C) burst index; (D) tear index. 
effect on the drainage rate. Instead, a slight detrimental effect was measured for the latter enzyme extract ( $5 \%$ decrease of drainage rate). These results may be related with the different fibre solubilisation rates or modes of action. The improved drainability rate results in faster machine speed, which yields significant savings in energy and thus in overall cost. In addition, much more recycled fibre will be used in paper making, reducing the requirement of virgin pulp production, thus resulting in great saving in energy required for pulping, bleaching, refining, etc., which will eventually lead to lower environmental pollution problems (Bajpai et al., 1999).

\section{Acknowledgements}

The authors gratefully thank Portucel, S.A. (Viana do Castelo, Portugal) for the use of laboratory facilities for the pulp and paper characterisation and the Portuguese Government for funding this research under the PRAXIS Programme (contract PRAXIS/BIO/1133/95). SM and HP have received individual grants from PRAXIS (BIC/3087/96 and BD/3253/96, respectively), which are acknowledged.

\section{References}

Ackermann, C.H.-J., Putz, G., 1999. Effect of pulping conditions on deinking of wood. Pulp Paper Can. 100, 37-41.

Anne, L., Morkbak, P.D., Zimmermann, W., 1999. Deinking of soy bean oil based ink printed paper with lipases and a neutral surfactant. J. Biotechnol. 67, 229-236.

Bajpai, P., Bajpai, P.K., Kondo, R., 1999. Biotechnology for Environmental Protection in the Pulp and Paper Industry. Springer, Berlin, Germany.

Borchardt, J.K., 1993. Effect of process variables in laboratory deinking experiments. Tappi J. 76 (11), 147-154.

Duff, S.J.B., Moritz, J.W., Casavant, T.E., 1995. Effect of surfactant and particle size reduction on hydrolysis of deinking sludge and nonrecyclable newsprint. Biotechnol. Bioeng. 45, 239-244.

Fišerová, M., Opálená, E., Farkaš, J., 1987. Effect of hemicelluloses on the papermaking properties of the pulps prepared from poplar wood. Cellulose Chem. Technol. 21, $419-430$.

Gomes, I., Gomes, J., Steiner, W., Esterbauer, H., 1992. Production of cellulase and xylanase by a wild strain of
Trichoderma viride. Appl. Microbiol. Biotechnol. 36, $701-$ 707.

Gübitz, G.M., Mansfield, S.D., Böhm, D., Sadler, J.N., 1998. Effect of endoglucanases and hemicellulases in magnetic and flotation deinking of xerographic and laser-printed papers. J. Biotechnol. 65, 209-215.

Heise, O.U., Unwin, J.P., Klungness, J.H., Fineran, W.G., Sikes, M., Abubakr, S., 1996. Industrial scaleup of enzymeenhanced deinking of nonimpact printed toners. Tappi J. 79 (3), 207-212.

Hrmová, M., Biely, P., Vrsanská, M., 1989. Cellulose- and xylan-degrading enzymes of Aspergillus terreus and Aspergillus niger. Enzyme Microb. Technol. 11, 611-616.

Jeffries, T.W., Klungness, J.H., Sykes, M.S., Rutledge, C.K.R., 1993. Preliminary results of enzyme-enhanced versus conventional deinking of xerographic printed paper. In: Tappi 1993 Recycling Symposium Notes. Tappi Press, Atlanta, USA, pp. 183-188.

Jeffries, T.W., Klungness, J.H., Sykes, M.S., Rutledge, C.K.R., 1994. Comparison of enzyme-enhanced with conventional deinking of xerographic and laser-printed paper. Tappi J. 77 (4), 173-179.

Jobbins, J.M., Franks, N.E., 1997. Enzymatic deinking of mixed office waste-process condition optimization. Tappi J. 80 (9), 73-78.

Li, X.L., Zhuang, Z.Q., Dean, J.F.D., Ericksson, K.-E., Ljungdahl, L.G., 1993. Purification and characterization of a new xylanase (APX-II) from the fungus Aureobasidium pullulans Y-2311-1. Appl. Environ. Microbiol. 59, 32123218.

Miller, G.L., 1959. Use of dinitrosalicylic acid reagent for determination of reducing sugar. Anal. Chem. 31, 420-428.

Ow, S.K., Park, J.M., Han, S.H., 1995. Effects of enzyme on ink size and distribution during the enzymatic deinking process of old newsprint. In: Proceeding of 6th International Conference on Biotechnol. Pulp and Paper Industry, Vienna, Austria, pp. 163-168.

Pala, H., Lemos, M.A., Mota, M., Gama, F.M., 2001. Enzymatic upgrade of old paperboard containers. Enzyme Microb. Technol. 29, 274-279.

Prasad, D.Y., 1993. Enzymatic deinking of laser and xerographic office wastes. Appita 46, 289-292.

Prasad, D.Y., Heitmann, J.A., Joyce, T.W., 1992. Enzyme deinking of black and white letterpress printed newsprint waste. Prog. Paper Recycl. 1, 21-30.

Prasad, D.Y., Heitmann, J.A., Joyce, T.W., 1993. Enzymatic deinking of colored offset newsprint. Nor. Pulp Paper Res. J. 2, 284-286.

Putz, H.J., Renner, K., Göttsching, L., Jokinen, O., 1994. Enzymatic deinking in comparison with conventional deinking offset news. In: Proceedings of the 1994 Tappi Pulp Conference. Tappi Press, Atlanta, USA, pp. 877-884.

Rushing, W., Joyce, T.W., Heitmann, J.A., 1993. Hydrogen peroxide bleaching of enzyme deinked old newsprint. In: Proceedings of the Seventh International Symposium on Wood and Pulping Chemistry, Beijing, China, pp. 233-238. 
Rutledge, C.K.R., Klungness, J.H., Sykes, M., Jeffries, T., 1994. Preliminary results of effect of sizings on enzymeenhanced deinking. In: Proceedings of the 1994 Tappi Recycling Symposium. Tappi Press, Atlanta, USA, pp. $103-105$.

Suurnäkki, A., Tenkanen, M., Buchert, J., Viikari, L., 1997. Hemicellulases in the bleaching of chemical pulps. Adv. Biochem. Eng. Biotechnol. 57, 261-287.

Vishniac, W., Santer, M., 1957. The thiobacilli. Bacteriol. Rev. 21, 95-213.

Welt, T., Dinus, R., 1995. Enzymatic deinking. Prog. Pap. Recycling 4, 36-47.
Woodward, J.L., Stephan, M., Koran, L.J., Wong, K.K.Y., Saddler, J.N., 1994. Enzymatic separation of high-quality uninked pulp fibers from recycled newspaper. Bio/Technology $12,905-908$.

Zeyer, C., Joyce, T.W., Heitmann, J.A., Rucker, J.W., 1994. Factors influencing enzyme deinking of recycled fiber. Tappi J. 77 (10), 169-177.

Zeyer, C., Heitmann, J.A., Joyce, T.W., 1995. Performance study of enzymatic deinking using cellulase/hemicellulase blends. In: Proceedings of the 6th International Conference on Biotechnol. Pulp and Paper Industry, Vienna, Austria, pp. $169-172$. 